\title{
The convergence of the French and the German economies as an effect of the European globalization and the economic effects on both economies.
}

\author{
Mariya Kicheva-Kirova, Tsvetomir Tsvetkov, Lyubov Ivanova \\ „Neophit Rilski“ South West University Blagoevgrad, Bulgaria \\ Department of Economics
}

\begin{abstract}
:
The globalization in Europe is manifested through the creation of the European Union and the euro area. Both unions lead to a convergence of European economies in political and economic terms. The economic and political rapprochement between France and Germany is at the heart of globalization in Europe. Therefore, this article examines the extent of this convergence and its effect on the economy of Germany and France. The study is performed by regression analysis using the least-squares method with a cross-section. The following conclusions are drawn: The convergence between the economies of the two countries has a positive effect on their economies. The integration of the French and German economies must continue because it creates a sustainable dynamic for the economic growth of Germany and France. The convergence of the economies of France and Germany leads to a slightly better effect on the German economy.
\end{abstract}

Keywords: economic growth, economic cohesion, globalization

\section{Introduction}

The economic and the political rapprochement of Germany and France began in 1963 with the signing of the Elysee Treaty. It then went through the collapse of the Berlin Wall and the unification of Germany, which gave a new impetus to the globalization and the integration processes of cohesion. In 1999, the adoption of the common European currency by the two countries ended the monetary union between France and Germany. Germany and France, following the signing of the Aachen Treaty, further strengthened the rapprochement between the two countries and the economic cooperation between them.

The economic and political cohesion of France and Germany will make the globalization in Europe even more sustainable and rapid. It will also enhance the positive effects on the economies of France and Germany themselves, creating the preconditions for their faster growth and economic growth.

This article examines the degree of convergence between Germany and France by conducting a correlation analysis for the period 1991-2018. A strong degree of convergence is established. The main objective of the study is to reduce the effects of the convergence of the economies of France and Germany on their economic growth. The objective is achieved by applying a regression analysis using the method of least squares with a cross section. The study period is 1991-2018. The variables under consideration are GDP and imports and exports. The study uses first differences of the dynamic rows of the variables considered. It is 
concluded that the convergence of the economies of Germany and France leads to positive effects, both on the economy of France and on the economy of Germany.

\section{Literature View}

The globalization in Europe is expressed through the European Union (EU) and the euro area, which are political and economic unions that lead to the convergence of the economies of the countries participating in those unions. The greatest degree of globalization is the convergence of countries and their economic integration, which takes the form of a common currency in the euro area. It is the convergence of the economies of Germany and France in the real and monetary sphere that expresses the process of globalization to the full. This cohesion and the interaction is a characteristic of the essence of the globalization that must be examined in order to see the effects of globalization on the two most important economies in the EU and the euro area. According to Prof. Alexander Tomov: "Increasing the volume of the world production accelerates both the speed of change and the mutual penetration of the development patterns in the different countries"1

An important question is how the economies of Germany and France evolve under the influence of the globalization, which leads to their full monetary mutual integration, through the euro and the convergence of the real economies.

The globalization is a process of convergence between the economies of France and Germany and this convergence must lead to an increase in the GDP of each country. According to a number of authors such as Daniel S. Hamilton and Joseph P. Quinlan ${ }^{2}$, Axel Dreher $^{3}$, Joaquin Vial ${ }^{4}$, Victor. E. Tokman ${ }^{5}$, Kilic, ${ }^{6}$ the globalization has a positive impact on the economic growth. It follows from this conclusion that the convergence of the economies between the different countries has a positive effect on the economic growth of each of the countries participating in this convergence. This thesis has been developed by Adam Smith ${ }^{7}$, who argues that the free international trade between the two countries that specialized in the production of certain goods through division of labor leads to a mutual increase in GDP. In other words, Smith argues that the convergence of two economies

\footnotetext{
${ }^{1}$ Tomov, A.,(2017): Novite globalni sili I Evropa, Universitetsko izdatelstvo "Sv. Kiril I Metodii”, Sofia, Bulgaria, p.218 [Томов, А., (2017) Новите глобални сили и Европа, Университетско издателство „Св. Кирил и Методий“, София, Българиа, стр.218. ]

2 Hamilton S. D., Quinlan P. J. (2008): „Germany and Globalization“, Washington, DC: Center for Transatlantic Relations. https://www.files.ethz.ch/isn/96218/2008_GermanyandGlobalization_EN.pdf

3 Dreher, A., (2005): „Does Globalization Affect Growth? Evidence from a new Index of Globalization“, Research Paper Series, TWI and University of Konstanz, pp. 2-19.

https://pdfs.semanticscholar.org/a5ce/cb531920ca4afffa4faaf94b0098e4989795.pdf

${ }^{4}$ Vial, A., (2018): Globalisation and the Chilean economy, a chapter in Globalisation and deglobalisation, from Bank for International Settlements, vol. 100, pp 83-100. https://www.bis.org/publ/bppdf/bispap100.pdf

${ }^{5}$ Tokman , E., V., (2010): Globalization in Chile: A Positive Sum of Winners and Losers, International Centre for Trade and Sustainable Development (ICTSD), Geneva, Switzerland, 2010, pp. 33-35.

https://www.ictsd.org/sites/default/files/research/2010/12/globalization-in-chile.pdf

${ }^{6}$ Kilic, C.(2005): „Effects of Globalization on Economic Growth: Panel Data Analysis for Developing Countries“, Economic Insights - Trends and Challenges, Vol.IV(LXVII), pp. 1 - 11. http://www.upgbulletin-se.ro/archive/2015-1/1.Kilic.pdf

${ }^{7}$ Smith A., (2018): „The Wealth of Nations“, CreateSpace Independent Publishing Platform (November 1, 2018), ISBN 10:1505577128 ISBN 13: 9781505577129.
} 
through international trade leads to their mutual economic development. This logic is deeply rooted in the globalization and its main feature is the convergence of countries. David Ricardo $^{8}$, also develops a theory of шге comparative relative advantages, which states that, regardless of the size and development of the country, any country can participate in the international trade, which will allow it to realize GDP growth. The theoretical principle of the comparative relative advantages gives the greatest justification for the global process of the convergence of the economies. In fact, Ricardo, by inferring the principle of the relative advantages, fully substantiates the thesis that the convergence of the economies would lead to mutual economic benefits for both interconnected economies. Heckscher and Ohli ${ }^{9}$ develop a theory of international trade known as "Theory of the ratio of the production factors". This theory argues that each country must produce and export the goods that are most relevant to its production factors. Thus, when countries export goods that correspond to their factors of production, which have and import goods that require factors of production that they do not have in abundance in international trade, it will be positive for both countries. Therefore, Heckscher and Olin justify, as Smith and Ricardo do, the benefits of the converging the two economies.

The globalization is a process of convergence of economies, which can, however, have negative consequences, apart from the positive ones, according to some authors such as Joseph Eugene Stiglitz ${ }^{10}$. Carles Xavier Simo Noguera, Asunción Soro Bonmatí and Teresa Castro-Martin ${ }^{11}$, analyzing the globalization, they conclude that greater economic uncertainty is being created which leads to negative economic effects of the globalization.

\section{Features and methodology of the study}

The dependence and the convergence of the economies of Germany and France is examined. The restrictive conditions of the study are limited to the time period 1991-2018. The Eurostat database is used. The variables under study are the following:

GDPGER - Gross domestic product of Germany

GDPFRAN - Gross domestic product of France

EXFRAN - export of France

EXGER - export of Germany

IMFRAN - imports of France

IMGER - imports of France

The research software used is Eviews7.

The following empirical procedures are performed. Namely, regression and correlation analysis. The application of regression and correlation analysis is preceded by a stationarity

\footnotetext{
${ }^{8}$ Ricardo D., (2004): „The Principles of Political Economy and Taxation“, Dover Publications, ISBN-10: 0486434613/ISBN-13: 978-0486434612.

${ }^{9}$ Heckscher E., Ohli, B., (1991): „Trade Theory“, The MIT Press, ISBN 10: 0262082012 / ISBN 13: 9780262082013.

${ }^{10}$ Stiglitz, E. J., (2002): „Globalization and Its Discontents“, W.W.Norton\&Company, New York and London, United States of America, First Edition, pp. ix-xi.

${ }^{11}$ Noguera, S. X., Castro-Martin T., Bonmatí S.A., (2005): The Spanish case: The effects of the globalization process on the transition to Adulthood, In book: Globalization, uncertainty and youth in society, Chapter: 15, Publisher: Routledge.Taylor\&FrancisGroup, pp. 373 - 381. https://www.researchgate.net/publication/257613737_The_Spanish_case_The_effects_of_the_globali zation_process_on_the_transition_to_adulthood
} 
test. The stationarity process is characterized as a Gaussian distribution, which means that the values of the variables over time will have the same distribution with above and below the average $^{12}$. A process is defined as stochastic and stationary when:

(1) $E\left(Y_{t_{1}}^{l_{1}} \ldots Y_{t_{n}}^{l_{n}}\right)=\left(Y_{t_{1}+s}^{l_{1}} \ldots Y_{t_{n}+s}^{l_{n}}\right)$.

The process is characterized by the following specifics:

$$
\begin{aligned}
& \mathrm{E}\left(\mathrm{Y}_{\mathbf{t}}\right)=E Y_{t+s}=\mu<\infty \\
& \mathrm{E}\left(\boldsymbol{Y}_{t}^{\mathbf{2}}\right)=E \boldsymbol{Y}_{t+s}^{\mathbf{2}}=\boldsymbol{\sigma}^{\mathbf{2}}<\infty \\
& \operatorname{cov}\left(Y_{t_{1}}, Y_{t_{2}}\right)=\operatorname{cov}\left(Y_{t_{1+s}}, Y_{t_{2+s}}\right)=Y_{t_{1}, t_{2}}=Y_{s}<\infty
\end{aligned}
$$

Where $t_{1}-t_{2}=s$.

Strong stationarity is manifested under the following condition:

(3) $\mathrm{E}\left(\mathrm{Y}_{\mathbf{t}}\right)=\mathrm{E} Y_{t+s}=\mu<\infty$ is met.

A weak stationarity under the following condition:

(4) $\operatorname{cov}\left(Y_{t_{1}}, Y_{t_{2}}\right)=\operatorname{cov}\left(Y_{t_{1+s}} Y_{t_{2+s}}\right)=Y_{t_{1}, t_{2}}=Y_{s}<\infty$.

There is no autocorrelation when the following condition is fulfilled:

(5) $\mathrm{E}\left(\boldsymbol{Y}_{t}^{\mathbf{Z}}\right)=E \boldsymbol{Y}_{t+s}^{\mathbf{Z}}=\boldsymbol{\sigma}^{\mathbf{2}}<\infty$.

In the case of a normal Gaussian stationarity process, second-order stationarity is the equivalent of full stationarity ${ }^{13}$

The stationarity is manifested under the following condition:

(6)

$$
\Delta y_{t}=\alpha Y_{t-1}+x_{t}^{\prime}+\varepsilon_{t}
$$

The null hypothesis states that we have a single root :

(7) $\mathrm{H}_{\mathbf{0}}: \boldsymbol{\alpha}=\mathbf{0}$

(8) $\mathbf{H}_{\mathbf{1}}: \boldsymbol{\alpha}<\mathbf{0}$

The alternative hypothesis states that the process is stationary.

The regression model is described by the following equation:

(9) $y=\alpha+\beta \mathrm{X}+\boldsymbol{\epsilon}$

Where:

$y$ - dependent variable

$\alpha$ - regression coefficient

$\beta$ - regression coefficient

$\mathrm{x}$ - independent variable

$\epsilon$ - variable of interference

\footnotetext{
${ }^{12}$ Dasgupta, A. \& A. Wahed. (2014). Laboratory Statistics and Quality Control, Chapter 4 - in (Ed.): A. Dasgupta, A. Wahed, (15 June, 2019 Clinical Chemistry, Immunology and Laboratory Quality Control, Elsevier, pp. 47-66, ISBN 9780124078215, https://doi.org/10.1016/B978-0-12-407821-5.00004-8. ${ }^{13}$ Petkov, P. (2008). Econometrics. Academic Publishing House "Tsenov", Svishtov (in Bulgarian language), pp. 147-146.
} 


\section{Analysis of the empirical results}

The considered variables GDP, exports and imports of France and Germany are characterized as non-stationary. Therefore, the first difference stationarity test is apllied.

\begin{tabular}{|c|c|c|c|c|}
\hline $\begin{array}{l}\text { Augmented Dickey- } \\
\text { Fuller test statistic }\end{array}$ & \multicolumn{2}{|c|}{ Test critical values: } & t-Statistic & Prob. \\
\hline \multirow[t]{3}{*}{ GDPGER } & $1 \%$ level & -3.724070 & \multirow[t]{3}{*}{1.568600} & \multirow[t]{3}{*}{0.9990} \\
\hline & $5 \%$ level & -2.986225 & & \\
\hline & $10 \%$ level & -2.632604 & & \\
\hline \multirow[t]{3}{*}{ GDPFRAN } & $1 \%$ level & -3.699871 & \multirow[t]{3}{*}{-0.631703} & \multirow[t]{3}{*}{0.8474} \\
\hline & $5 \%$ level & -2.976263 & & \\
\hline & $10 \%$ level & -2.627420 & & \\
\hline \multirow[t]{3}{*}{ EXFRAN } & $1 \%$ level & -3.699871 & \multirow[t]{3}{*}{-0.120045} & \multirow[t]{3}{*}{0.9374} \\
\hline & $5 \%$ level & -2.976263 & & \\
\hline & $10 \%$ level & -2.627420 & & \\
\hline \multirow[t]{3}{*}{ EXGER } & $1 \%$ level & -3.699871 & \multirow[t]{3}{*}{0.550092} & \multirow[t]{3}{*}{0.9854} \\
\hline & $5 \%$ level & -2.976263 & & \\
\hline & $10 \%$ level & -2.627420 & & \\
\hline \multirow[t]{3}{*}{ IMFRAH } & $1 \%$ level & -3.699871 & \multirow[t]{3}{*}{0.052875} & \multirow[t]{3}{*}{0.9556} \\
\hline & $5 \%$ level & -2.976263 & & \\
\hline & $10 \%$ level & -2.627420 & & \\
\hline \multirow[t]{3}{*}{ IMGER } & $1 \%$ level & -3.699871 & \multirow[t]{3}{*}{0.610498} & \multirow[t]{3}{*}{0.9873} \\
\hline & $5 \%$ level & -2.976263 & & \\
\hline & $10 \%$ level & -2.627420 & & \\
\hline \multirow{2}{*}{$\begin{array}{l}\text { Augmented Dickey- } \\
\text { Fuller Test Statistic } \\
\text { Difference }\end{array}$} & \multicolumn{2}{|c|}{ Test Critical Values: } & t-Statistic & Prob. \\
\hline & \multicolumn{2}{|l|}{ Difference } & Difference & Difference \\
\hline \multirow{3}{*}{ D(GDPGER) } & $1 \%$ level & -3.711457 & \multirow[t]{3}{*}{-4.028346} & \multirow[t]{3}{*}{0.0047} \\
\hline & $5 \%$ level & -2.981038 & & \\
\hline & $10 \%$ level & -2.629906 & & \\
\hline \multirow[t]{3}{*}{ D(GDPFRAW) } & $1 \%$ level & -3.711457 & \multirow[t]{3}{*}{-4.400287} & 0.0019 \\
\hline & $5 \%$ level & -2.981038 & & \\
\hline & $10 \%$ level & -2.629906 & & \\
\hline D(EXFRAW) & $1 \%$ level & -3.711457 & -5.589056 & 0.0001 \\
\hline & $5 \%$ level & -2.981038 & & \\
\hline & $10 \%$ level & -2.629906 & & \\
\hline D(EXGER) & $1 \%$ level & -3.737853 & -4.652148 & 0.0012 \\
\hline & $5 \%$ level & -2.991878 & & \\
\hline & $10 \%$ level & -2.635542 & & \\
\hline D(IMFRAK) & $1 \%$ level & -3.769597 & -4.618535 & 0.0015 \\
\hline & $5 \%$ level & -3.004861 & & \\
\hline & $10 \%$ level & -2.642242 & & \\
\hline D(IMGER) & $1 \%$ level & -3.769597 & -3.853344 & 0.0083 \\
\hline & $5 \%$ level & -3.004361 & & \\
\hline & $10 \%$ level & -2642242 & & \\
\hline
\end{tabular}

Source: Eurostat

Data: Authors`calculations

As it can be seen from the results, at the first difference, all the variables considered are stationary and we can proceed to regression analysis.

First, the relationship between Germany's GDP and France's GDP will be examined to determine if there is a convergence between the two economies. For that purpose, a 
correlation analysis is applied which may clarify the question of whether there is a link between the economies of Germany and France.

\section{Correlation analysis of the GDP ratio of Germany and France}

\begin{tabular}{|c|c|c|}
\hline & GDPGER & GDPFRAN \\
\hline GDPGER & 1.000000 & 0.970922 \\
\hline GDPFRAN & 0.970922 & 1.000000 \\
\hline
\end{tabular}

Figure 1

Source: Eurostat

Data: Authors`calculations

It is clear that we have a high degree of cohesion, which is an indicator of the process of globalization, which certainly determines this convergence between the economies of Germany and France and, respectively, influences their development.

GDP dynamics of Germany and France

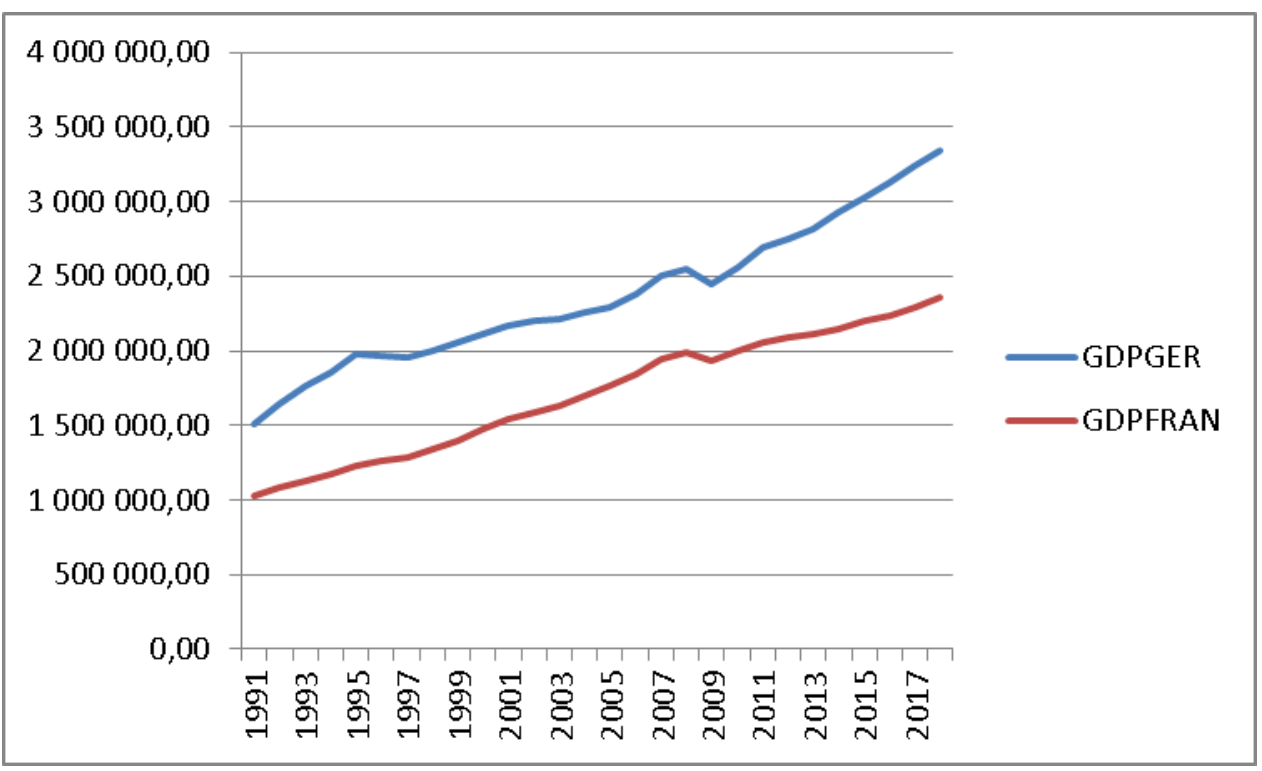

Data Source: Eurostat

The movement of the economic development trends in Germany and France register synchronous dynamics and dynamics. This synchronicity is an indicator that the two economies are interacting and converging, especially since 1999, when both countries adopted the euro as a common currency. Therefore, the complete monetary integration between the two countries contributes to the synchronized movement and rapprochement between France and Germany. It should be noted that the difference between Germany's GDP growth is greater than that of France. This difference speaks to the benefits of the convergence and interaction of the two economies. The functional relationship between the GDP of Germany and France will answer which economy has better effects in the process of convergence between the two. It will also reveal the effect of globalization and the convergence of 
economies on whether it is positive for the two economies and which economy benefits from the interaction between them.

The functional relationship between the GDP of Germany and France will answer which economy has better effects in the process of convergence between the two. It will also reveal the effect of globalization and the convergence of economies on whether it is positive for the two economies and which economy benefits from the interaction between them.

Figure 3

\section{The functional relationship between the economies of Germany and France}
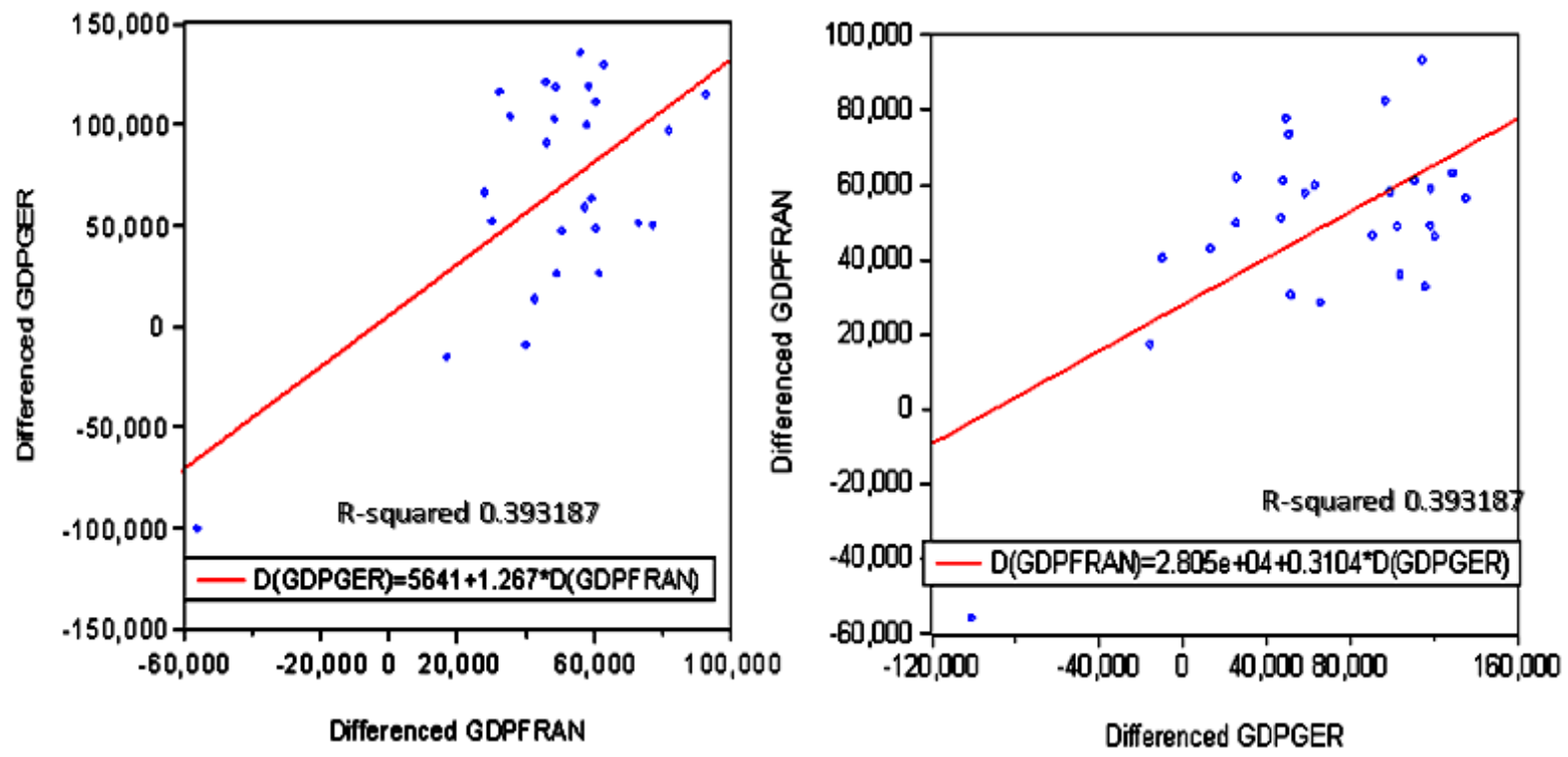

Data source: Eurostat

Data: Authors`calculations

The cohesion process, which is determined by the ongoing process of globalization, has a favorable effect on both the economies. The registration of economic growth in France has a greater positive impact on the German economy than the registration of economic growth in the German economy, which also leads to the growth of the French economy, but with a smaller one value. The determinant coefficient, which explains the change in the German economy with the change in the French economy is 0.39 , which means that only $39 \%$ of the dynamics of the German GDP is explained by the change in the French GDP. It can be seen that the change in Germany's GDP depends on other variables. On its part, the French GDP is again determined by 0.39 percent of the change in the economic growth of the German economy. From the empirical analysis, it can be deduced that the two economies in their interaction converge and influence each other positively, but their interaction cannot be considered as a determinant factor that determines their economic growth. In the process of interaction and cohesion, Germany realize greater benefits than France. 
Correlation between imports of France and exports of Germany

Figure 4

\begin{tabular}{|l|l|l|}
\hline & EXGER & IMFRAN \\
\hline EXGER & 1.000000 & 0.996152 \\
\hline IMFRAN & 0.996152 & 1.000000 \\
& & \\
\hline
\end{tabular}

Data source: Eurostat

Data: Authors`calculations

The correlation between Germany's foreign trade and France's foreign trade is very high, which is an indication of the very close convergence of the two economies.

Functional link between the imports of France and the exports of Germany
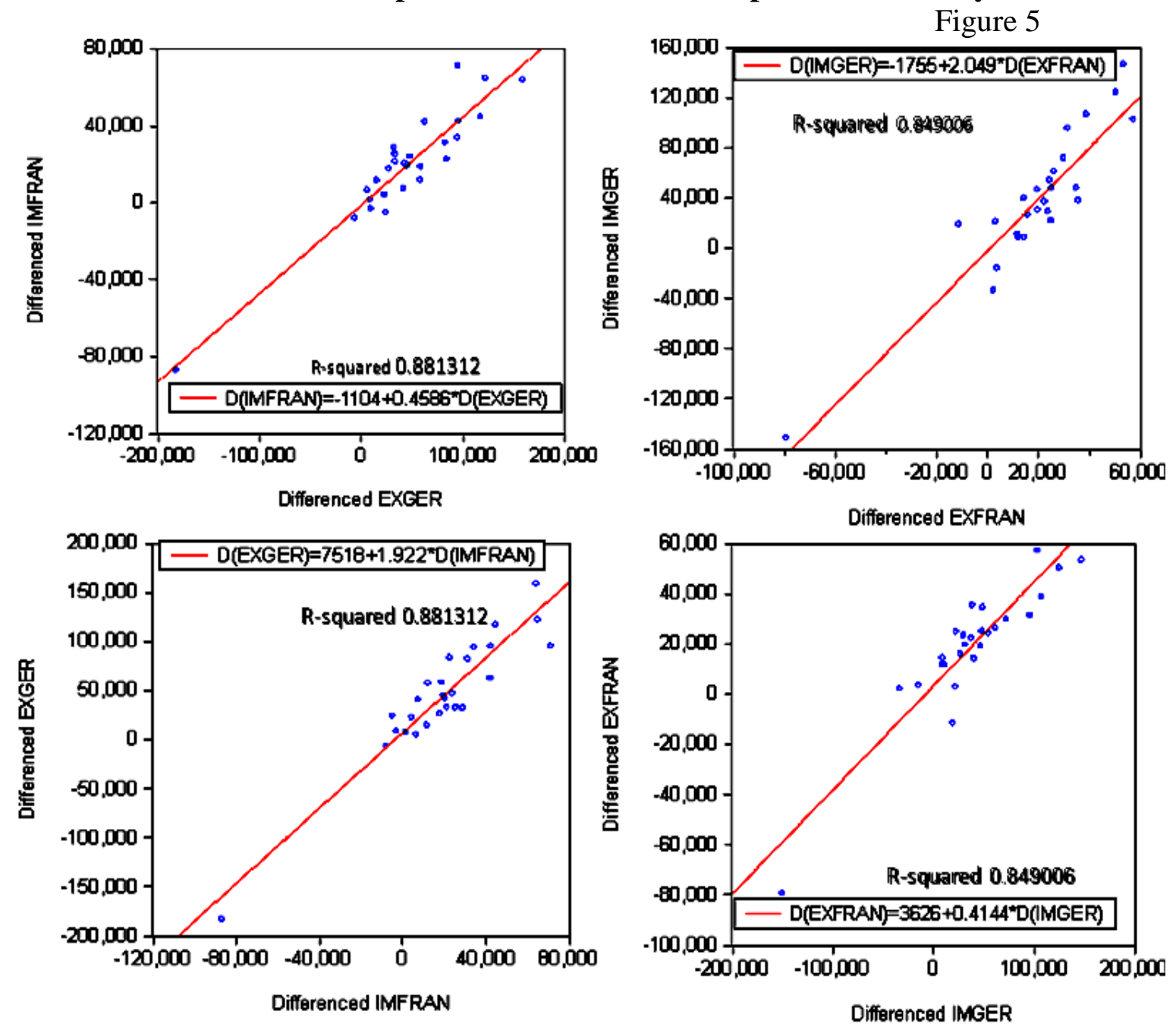

Data source: Eurostat

Differenced IMGER

Data: Authirs`calculations 
The increase in exports of both France and Germany has led to an increase in their imports, which confirms the above conclusion that the German and French economies are highly dependent on each other. The determination of imports from exports is high and positive for both countries. France benefits more from exports because it exports more goods and services to Germany than Germany to France. However, as imports into France increase, Germany manages to realize more exports than, when imports into Germany increase, the exports from France is smaller.

From the analysis made it can be deduced that both France and Germany benefit from the globalization and its effect on the convergence of economies. In the interaction between France and Germany, the German economy realize greater economic growth. And the French economy manages to export more goods and services to Germany. Therefore, Germany manages to export more innovative goods that have a great added value than France. It can also be said that Germany is a more open economy and the French economy is more closed.

\section{Conclusion}

The European globalization is realized through the economic and political cohesion of France and Germany. The strong interaction between the two economies creates positive economic effects for both economies. Therefore, the approximation between them must continue. The reason for the bilateral good economic effect is that both countries are highly developed. Several important conclusions emerge from the analysis. The first is that the international cohesion and trade have a positive impact on the economic growth, provided that the countries are relatively equally developed. The second conclusion is that the euro area and the EU must be preserved, because they contribute to the sustainable development of the participating countries. The third conclusion is that Germany and France must continue to converge.

\section{References:}

1. Tomov, A., (2017): Novite globalni sili I Evropa, Universitetsko izdatelstvo "Sv. Kiril I Metodii”, Sofia, Bulgaria, p.218 [Томов, А., (2017) Новите глобални сили и Европа, Университетско издателство „Св. Кирил и Методий“, София, България, стр.218]

2. Hamilton S. D., Quinlan P. J. (2008): „Germany and Globalization“, Washington, DC: Center for Transatlantic Relations.

3. https://www.files.ethz.ch/isn/96218/2008_GermanyandGlobalization_EN.pdf

4. Dreher, A., (2005): „Does Globalization Affect Growth? Evidence from a new Index of Globalization", Research Paper Series, TWI and University of Konstanz, pp. 2-19 .

5. https://pdfs.semanticscholar.org/a5ce/cb531920ca4afffa4faaf94b0098e4989795.pdf

6. Vial, A., (2018): Globalisation and the Chilean economy, a chapter in Globalisation and deglobalisation, from Bank for International Settlements, vol. 100, pp 83-100. https://www.bis.org/publ/bppdf/bispap100.pdf

7. Tokman , E., V., (2010): Globalization in Chile: A Positive Sum of Winners and Losers, International Centre for Trade and Sustainable Development (ICTSD), Geneva, Switzerland, 2010, pp. 33-35.

8. https://www.ictsd.org/sites/default/files/research/2010/12/globalization-in-chile.pdf 
9. Kilic, C.(2005): „Effects of Globalization on Economic Growth: Panel Data Analysis for Developing Countries", Economic Insights - Trends and Challenges, Vol.IV(LXVII), pp. 1 11. http://www.upg-bulletin-se.ro/archive/2015-1/1.Kilic.pdf

10. Smith A., (2018): „The Wealth of Nations“, CreateSpace Independent Publishing Platform (November 1, 2018), ISBN 10: 1505577128 ISBN 13: 9781505577129.

11. Ricardo D., (2004): „The Principles of Political Economy and Taxation“, Dover Publications, ISBN-10: 0486434613/ISBN-13: 978-0486434612.

12. Heckscher E., Ohli, B., (1991): „Trade Theory“, The MIT Press, ISBN 10: 0262082012 / ISBN 13: 9780262082013.

13. Stiglitz, E. J., (2002): „Globalization and Its Discontents“, W.W.Norton\&Company, New York and London, United States of America, First Edition, pp. ix-xi.

14. Noguera S.X., Castro-Martin T., Bonmatí S.A., (2005): The Spanish case: The effects of the globalization process on the transition to Adulthood, In book: Globalization, uncertainty and youth in society, Chapter: 15, Publisher: Routledge.Taylor\&FrancisGroup,pp.373-381.

15. https://www.researchgate.net/publication/257613737_The_Spanish_case_The_effects_of _the_globalization_process_on_the_transition_to_adulthood

16. Dasgupta, A. \& A. Wahed. (2014). Laboratory Statistics and Quality Control, Chapter 4 in (Ed.): A. Dasgupta, A. Wahed, (15 June, 2019 Clinical Chemistry, Immunology and Laboratory Quality Control, Elsevier, pp. 47-66, ISBN 9780124078215, https://doi.org/10.1016/B978-0-12-407821-5.00004-8.

17. Petkov, P. (2008). Econometrics. Academic Publishing House "Tsenov", Svishtov (in Bulgarian language), pp.147-146.

\section{Applications: Stationarity Tests}

Null Hypothesis: GDPGER has a unit root

Exogenous: Constant

Lag Length: 2 (Automatic - based on SIC, maxlag=6)

\begin{tabular}{lrcc}
\hline \hline & t-Statistic & Prob.* \\
\hline \hline Augmented Dickey-Fuller test statistic & 1.568600 & 0.9990 \\
\hline Test critical values: & 1\% level & -3.724070 & \\
& $5 \%$ level & -2.986225 & \\
& $10 \%$ level & -2.632604 & \\
\hline \hline
\end{tabular}

*MacKinnon (1996) one-sided p-values.

Augmented Dickey-Fuller Test Equation

Dependent Variable: D(GDPGER)

Method: Least Squares

Date: 11/13/19 Time: 08:04

Sample (adjusted): 19942018

Included observations: 25 after adjustments

\begin{tabular}{lllll}
\hline \hline Variable & Coefficient & Std. Error & t-Statistic & Prob. \\
\hline \hline
\end{tabular}




\begin{tabular}{lrlrr}
\multicolumn{1}{c}{ GDPGER(-1) } & 0.042166 & 0.026881 & 1.568600 & 0.1317 \\
D(GDPGER(-1)) & 0.137293 & 0.206488 & 0.664896 & 0.5134 \\
D(GDPGER(-2)) & -0.284991 & 0.195059 & -1.461051 & 0.1588 \\
\multicolumn{1}{c}{ C } & -28205.40 & 62105.45 & -0.454153 & 0.6544 \\
\hline \hline R-squared & 0.191685 & Mean dependent var & 63035.94 \\
Adjusted R-squared & 0.076211 & S.D. dependent var & 53702.81 \\
S.E. of regression & 51615.88 & Akaike info criterion & 24.68669 \\
Sum squared resid & $5.59 \mathrm{E}+10$ & Schwarz criterion & 24.88171 \\
Log likelihood & -304.5837 & Hannan-Quinn criter. & 24.74078 \\
F-statistic & 1.659990 & Durbin-Watson stat & 2.022425 \\
Prob(F-statistic) & 0.206015 & & \\
\hline \hline
\end{tabular}

Null Hypothesis: GDPFRAN has a unit root

Exogenous: Constant

Lag Length: 0 (Automatic - based on SIC, maxlag=6)

\begin{tabular}{lrll}
\hline \hline & t-Statistic & Prob.* \\
\hline \hline Augmented Dickey-Fuller test statistic & -0.631703 & 0.8474 \\
\hline Test critical values: & $1 \%$ level & -3.699871 & \\
& $5 \%$ level & -2.976263 & \\
& $10 \%$ level & -2.627420 & \\
\hline \hline
\end{tabular}

*MacKinnon (1996) one-sided p-values.

Augmented Dickey-Fuller Test Equation

Dependent Variable: D(GDPFRAN)

Method: Least Squares

Date: 11/13/19 Time: 08:05

Sample (adjusted): 19922018

Included observations: 27 after adjustments

\begin{tabular}{lrlrr}
\hline \hline \multicolumn{1}{c}{ Variable } & Coefficient & \multicolumn{1}{c}{ Std. Error } & t-Statistic & Prob. \\
\hline \hline \multicolumn{1}{c}{ GDPFRAN(-1) } & -0.008427 & 0.013340 & -0.631703 & 0.5333 \\
\multicolumn{1}{c}{ C } & 63315.88 & 23082.31 & 2.743048 & 0.0111 \\
\hline \hline R-squared & 0.015711 & Mean dependent var & 49117.03 \\
Adjusted R-squared & -0.023660 & S.D. dependent var & 26967.58 \\
S.E. of regression & 27284.75 & Akaike info criterion & 23.33723 \\
Sum squared resid & $1.86 \mathrm{E}+10$ & Schwarz criterion & 23.43322 \\
Log likelihood & -313.0526 & Hannan-Quinn criter. & 23.36577 \\
F-statistic & 0.399048 & Durbin-Watson stat & 1.794865 \\
Prob(F-statistic) & 0.533316 & & \\
\hline \hline
\end{tabular}

Null Hypothesis: EXGER has a unit root

Exogenous: Constant

Lag Length: 0 (Automatic - based on SIC, maxlag=6) 


\begin{tabular}{lccc} 
& \multicolumn{1}{c}{ t-Statistic } & Prob. $^{*}$ \\
\hline \hline \multicolumn{2}{l}{ Augmented Dickey-Fuller test statistic } & 0.550092 & 0.9854 \\
\hline Test critical values: & 1\% level & -3.699871 & \\
& 5\% level & -2.976263 & \\
$10 \%$ level & -2.627420 & \\
\hline \hline
\end{tabular}

*MacKinnon (1996) one-sided p-values.

Augmented Dickey-Fuller Test Equation

Dependent Variable: D(EXGER)

Method: Least Squares

Date: 11/13/19 Time: 08:06

Sample (adjusted): 19922018

Included observations: 27 after adjustments

\begin{tabular}{lrlrr}
\hline \hline \multicolumn{1}{c}{ Variable } & Coefficient & Std. Error & t-Statistic & Prob. \\
\hline \hline \multicolumn{1}{c}{ EXGER(-1) } & 0.017550 & 0.031904 & 0.550092 & 0.5871 \\
\multicolumn{1}{c}{ C } & 30454.90 & 29789.84 & 1.022325 & 0.3164 \\
\hline \hline R-squared & 0.011959 & Mean dependent var & 45476.44 \\
Adjusted R-squared & -0.027562 & S.D. dependent var & 61028.36 \\
S.E. of regression & 61863.69 & Akaike info criterion & 24.97444 \\
Sum squared resid & $9.57 \mathrm{E}+10$ & Schwarz criterion & 25.07043 \\
Log likelihood & -335.1550 & Hannan-Quinn criter. & 25.00298 \\
F-statistic & 0.302601 & Durbin-Watson stat & 2.250131 \\
Prob(F-statistic) & 0.587138 & & \\
\hline
\end{tabular}

Null Hypothesis: EXFRAN has a unit root

Exogenous: Constant

Lag Length: 0 (Automatic - based on SIC, maxlag=6)

\begin{tabular}{lccc}
\hline \hline & t-Statistic & Prob.* \\
\hline \hline Augmented Dickey-Fuller test statistic & -0.120045 & 0.9374 \\
\hline Test critical values: & $1 \%$ level & -3.699871 & \\
& $5 \%$ level & -2.976263 & \\
& $10 \%$ level & -2.627420 & \\
\hline \hline
\end{tabular}

*MacKinnon (1996) one-sided p-values.

Augmented Dickey-Fuller Test Equation

Dependent Variable: D(EXFRAN)

Method: Least Squares

Date: 11/13/19 Time: 08:06

Sample (adjusted): 19922018

Included observations: 27 after adjustments

\begin{tabular}{lllll}
\hline \hline Variable & Coefficient & Std. Error & t-Statistic & Prob. \\
\hline \hline
\end{tabular}




\begin{tabular}{lrlrr}
\multicolumn{1}{r}{ EXFRAN(-1) } & -0.004055 & 0.033780 & -0.120045 & 0.9054 \\
\multicolumn{1}{c}{ C } & 21050.38 & 16220.22 & 1.297786 & 0.2062 \\
\hline \hline R-squared & 0.000576 & Mean dependent var & 19196.47 \\
Adjusted R-squared & -0.039401 & S.D. dependent var & 25276.28 \\
S.E. of regression & 25769.42 & Akaike info criterion & 23.22295 \\
Sum squared resid & $1.66 \mathrm{E}+10$ & Schwarz criterion & 23.31894 \\
Log likelihood & -311.5098 & Hannan-Quinn criter. & 23.25149 \\
F-statistic & 0.014411 & Durbin-Watson stat & 2.246713 \\
Prob(F-statistic) & 0.905407 & & \\
\hline
\end{tabular}

Null Hypothesis: IMFRAN has a unit root

Exogenous: Constant

Lag Length: 0 (Automatic - based on SIC, maxlag=6)

\begin{tabular}{lccc}
\hline \hline & t-Statistic & Prob.* \\
\hline \hline Augmented Dickey-Fuller test statistic & 0.052875 & 0.9556 \\
\hline Test critical values: & $1 \%$ level & -3.699871 & \\
& $5 \%$ level & -2.976263 & \\
& $10 \%$ level & -2.627420 & \\
\hline \hline
\end{tabular}

*MacKinnon (1996) one-sided p-values.

Augmented Dickey-Fuller Test Equation

Dependent Variable: D(IMFRAN)

Method: Least Squares

Date: 11/13/19 Time: 08:07

Sample (adjusted): 19922018

Included observations: 27 after adjustments

\begin{tabular}{lrlll}
\hline \hline \multicolumn{1}{c}{ Variable } & Coefficient & \multicolumn{1}{c}{ Std. Error } & t-Statistic & Prob. \\
\hline \hline \multicolumn{1}{c}{ IMFRAN(-1) } & 0.001884 & 0.035636 & 0.052875 & 0.9583 \\
\multicolumn{1}{c}{ C } & 18894.12 & 17232.69 & 1.096412 & 0.2833 \\
\hline \hline R-squared & 0.000112 & Mean dependent var & 19751.19 \\
Adjusted R-squared & -0.039884 & S.D. dependent var & 29811.55 \\
S.E. of regression & 30400.23 & Akaike info criterion & 23.55348 \\
Sum squared resid & $2.31 \mathrm{E}+10$ & Schwarz criterion & 23.64946 \\
Log likelihood & -315.9719 & Hannan-Quinn criter. & 23.58202 \\
F-statistic & 0.002796 & Durbin-Watson stat & 2.215194 \\
Prob(F-statistic) & 0.958251 & & \\
\hline \hline
\end{tabular}

Null Hypothesis: IMGER has a unit root

Exogenous: Constant

Lag Length: 0 (Automatic - based on SIC, maxlag=6)

\begin{tabular}{llc}
\hline \hline & t-Statistic & Prob.* \\
\hline \hline
\end{tabular}




\begin{tabular}{lccc} 
Augmented Dickey-Fuller test statistic & 0.610498 & 0.9873 \\
\hline Test critical values: & $1 \%$ level & -3.699871 & \\
& 5\% level & -2.976263 & \\
$10 \%$ level & -2.627420 & \\
\hline
\end{tabular}

*MacKinnon (1996) one-sided p-values.

Augmented Dickey-Fuller Test Equation

Dependent Variable: D(IMGER)

Method: Least Squares

Date: 11/13/19 Time: 08:07

Sample (adjusted): 19922018

Included observations: 27 after adjustments

\begin{tabular}{lrlll}
\hline \hline \multicolumn{1}{c}{ Variable } & Coefficient & \multicolumn{1}{c}{ Std. Error } & t-Statistic & Prob. \\
\hline \multicolumn{1}{c}{ IMGER(-1) } & 0.022551 & 0.036939 & 0.610498 & 0.5470 \\
\multicolumn{1}{c}{ C } & 20421.08 & 30150.49 & 0.677305 & 0.5044 \\
\hline \hline R-squared & 0.014689 & Mean dependent var & 37571.51 \\
Adjusted R-squared & -0.024723 & S.D. dependent var & 56197.48 \\
S.E. of regression & 56887.93 & Akaike info criterion & 24.80674 \\
Sum squared resid & $8.09 E+10$ & Schwarz criterion & 24.90273 \\
Log likelihood & -332.8910 & Hannan-Quinn criter. & 24.83528 \\
F-statistic & 0.372707 & Durbin-Watson stat & 2.205882 \\
Prob(F-statistic) & 0.547043 & & \\
\hline \hline
\end{tabular}

\section{Stationarity tests first difference}

Null Hypothesis: D(GDPGER) has a unit root

Exogenous: Constant

Lag Length: 0 (Automatic - based on SIC, maxlag=6)

\begin{tabular}{lrll}
\hline \hline & t-Statistic & \multirow{2}{*}{ Prob.* } \\
\hline \hline Augmented Dickey-Fuller test statistic & -4.028346 & 0.0047 \\
\hline Test critical values: & $1 \%$ level & -3.711457 & \\
& $5 \%$ level & -2.981038 & \\
& $10 \%$ level & -2.629906 & \\
\hline \hline
\end{tabular}

*MacKinnon (1996) one-sided p-values.

Augmented Dickey-Fuller Test Equation

Dependent Variable: D(GDPGER,2)

Method: Least Squares

Date: 11/13/19 Time: 08:08

Sample (adjusted): 19932018

Included observations: 26 after adjustments

\begin{tabular}{ccccc}
\hline \hline Variable & Coefficient & Std. Error & t-Statistic & Prob. \\
\hline \hline D(GDPGER(-1)) & -0.781715 & 0.194054 & -4.028346 & 0.0005 \\
\end{tabular}




\begin{tabular}{lrlr}
\multicolumn{1}{c}{ C } & 50708.93 & \multicolumn{1}{c}{16657.19} & 3.044267 \\
\hline \hline R-squared & 0.403394 & Mean dependent var & 0.0056 \\
Adjusted R-squared & 0.378536 & S.D. dependent var & -1383.281 \\
S.E. of regression & 53537.40 & Akaike info criterion & 67912.42 \\
Sum squared resid & $6.88 \mathrm{E}+10$ & Schwarz criterion & 24.68795 \\
Log likelihood & -318.9434 & Hannan-Quinn criter. & 24.78473 \\
F-statistic & 16.22757 & Durbin-Watson stat & 1.933630 \\
Prob(F-statistic) & 0.000490 & & \\
\hline \hline
\end{tabular}

Null Hypothesis: D(GDPFRAN) has a unit root

Exogenous: Constant

Lag Length: 0 (Automatic - based on SIC, maxlag=6)

\begin{tabular}{lrrr}
\hline \hline & t-Statistic & Prob.* \\
\hline \hline Augmented Dickey-Fuller test statistic & -4.400287 & 0.0019 \\
\hline Test critical values: & 1\% level & -3.711457 & \\
& 10\% level & -2.981038 & \\
& & -2.629906 & \\
\hline
\end{tabular}

*MacKinnon (1996) one-sided p-values.

Augmented Dickey-Fuller Test Equation

Dependent Variable: D(GDPFRAN,2)

Method: Least Squares

Date: 11/13/19 Time: 08:08

Sample (adjusted): 19932018

Included observations: 26 after adjustments

\begin{tabular}{lrlrr}
\hline \hline \multicolumn{1}{c}{ Variable } & Coefficient & \multicolumn{1}{c}{ Std. Error } & t-Statistic & Prob. \\
\hline \hline \multicolumn{1}{c}{ D(GDPFRAN(-1)) } & -0.893797 & 0.203122 & -4.400287 & 0.0002 \\
\multicolumn{1}{c}{ C } & 43658.64 & 11314.88 & 3.858516 & 0.0008 \\
\hline \hline R-squared & 0.446527 & Mean dependent var & 64.27692 \\
Adjusted R-squared & 0.423465 & S.D. dependent var & 36704.99 \\
S.E. of regression & 27870.05 & Akaike info criterion & 23.38230 \\
Sum squared resid & $1.86 \mathrm{E}+10$ & Schwarz criterion & 23.47907 \\
Log likelihood & -301.9699 & Hannan-Quinn criter. & 23.41016 \\
F-statistic & 19.36253 & Durbin-Watson stat & 1.936421 \\
Prob(F-statistic) & 0.000191 & & \\
\hline \hline
\end{tabular}

Null Hypothesis: D(EXGER) has a unit root

Exogenous: Constant

Lag Length: 2 (Automatic - based on SIC, maxlag=6)

\begin{tabular}{lcc}
\hline \hline & t-Statistic & Prob.* \\
\hline \hline Augmented Dickey-Fuller test statistic & -4.652148 & 0.0012 \\
\hline
\end{tabular}




$\begin{array}{ccc}\text { Test critical values: } & 1 \% \text { level } & -3.737853 \\ & 5 \% \text { level } & -2.991878 \\ 10 \% \text { level } & -2.635542\end{array}$

*MacKinnon (1996) one-sided p-values.

Augmented Dickey-Fuller Test Equation

Dependent Variable: D(EXGER,2)

Method: Least Squares

Date: 11/13/19 Time: 08:09

Sample (adjusted): 19952018

Included observations: 24 after adjustments

\begin{tabular}{lrlrl}
\hline \hline \multicolumn{1}{c}{ Variable } & Coefficient & \multicolumn{1}{c}{ Std. Error } & t-Statistic & Prob. \\
\hline \hline \multicolumn{1}{c}{ D(EXGER(-1)) } & -1.991433 & 0.428067 & -4.652148 & 0.0002 \\
D(EXGER(-1),2) & 0.703863 & 0.308113 & 2.284436 & 0.0334 \\
D(EXGER(-2),2) & 0.305775 & 0.208215 & 1.468553 & 0.1575 \\
\multicolumn{1}{c}{ C } & 95228.76 & 23225.85 & 4.100120 & 0.0006 \\
\hline \hline R-squared & 0.660879 & Mean dependent var & 602.1583 \\
Adjusted R-squared & 0.610010 & S.D. dependent var & 95502.08 \\
S.E. of regression & 59640.23 & Akaike info criterion & 24.98106 \\
Sum squared resid & $7.11 \mathrm{E}+10$ & Schwarz criterion & 25.17740 \\
Log likelihood & -295.7727 & Hannan-Quinn criter. & 25.03315 \\
F-statistic & 12.99198 & Durbin-Watson stat & 2.043756 \\
Prob(F-statistic) & 0.000062 & & \\
\hline \hline
\end{tabular}

Null Hypothesis: D(EXFRAN) has a unit root

Exogenous: Constant

Lag Length: 0 (Automatic - based on SIC, maxlag=6)

\begin{tabular}{lrcc}
\hline \hline & t-Statistic & \multirow{2}{*}{ Prob.* } \\
\hline \hline Augmented Dickey-Fuller test statistic & -5.589056 & 0.0001 \\
\hline Test critical values: & $1 \%$ level & -3.711457 & \\
& $5 \%$ level & -2.981038 & \\
& $10 \%$ level & -2.629906 & \\
\hline
\end{tabular}

*MacKinnon (1996) one-sided p-values.

Augmented Dickey-Fuller Test Equation

Dependent Variable: D(EXFRAN,2)

Method: Least Squares

Date: 11/13/19 Time: 08:09

Sample (adjusted): 19932018

Included observations: 26 after adjustments

\begin{tabular}{ccccc}
\hline \hline Variable & Coefficient & Std. Error & t-Statistic & Prob. \\
\hline \hline D(EXFRAN(-1)) & -1.133099 & 0.202735 & -5.589056 & 0.0000
\end{tabular}




\begin{tabular}{|c|c|c|c|}
\hline $\mathrm{C}$ & 21973.56 & 3.450285 & 0.0021 \\
\hline R-squared & 0.565513 & Mean dependent var & 695.6346 \\
\hline Adjusted R-squared & 0.547409 & S.D. dependent var & 38696.12 \\
\hline S.E. of regression & 26032.76 & Akaike info criterion & 23.24590 \\
\hline Sum squared resid & $1.63 \mathrm{E}+10$ & Schwarz criterion & 23.34268 \\
\hline Log likelihood & -300.1967 & Hannan-Quinn criter. & 23.27377 \\
\hline F-statistic & 31.23755 & Durbin-Watson stat & 2.062225 \\
\hline Prob(F-statistic) & 0.000009 & & \\
\hline
\end{tabular}

Null Hypothesis: D(IMFRAN) has a unit root

Exogenous: Constant

Lag Length: 4 (Automatic - based on SIC, maxlag=6)

\begin{tabular}{lrcc}
\hline \hline & t-Statistic & Prob.* \\
\hline \hline Augmented Dickey-Fuller test statistic & -4.618535 & 0.0015 \\
\hline Test critical values: & 1\% level & -3.769597 & \\
& 5\% level & -3.004861 & \\
& $10 \%$ level & -2.642242 & \\
\hline \hline
\end{tabular}

*MacKinnon (1996) one-sided p-values.

Augmented Dickey-Fuller Test Equation

Dependent Variable: D(IMFRAN,2)

Method: Least Squares

Date: 11/13/19 Time: 08:09

Sample (adjusted): 19972018

Included observations: 22 after adjustments

\begin{tabular}{lrlrr}
\hline \hline \multicolumn{1}{c}{ Variable } & Coefficient & \multicolumn{1}{c}{ Std. Error } & t-Statistic & Prob. \\
\hline \hline D(IMFRAN(-1)) & -3.862809 & 0.836371 & -4.618535 & 0.0003 \\
D(IMFRAN(-1),2) & 2.301419 & 0.695926 & 3.306988 & 0.0045 \\
D(IMFRAN(-2),2) & 1.543717 & 0.541095 & 2.852949 & 0.0115 \\
D(IMFRAN(-3),2) & 0.874411 & 0.361870 & 2.416370 & 0.0280 \\
D(IMFRAN(-4),2) & 0.386150 & 0.216376 & 1.784624 & 0.0933 \\
\multicolumn{1}{c}{ C } & 81186.54 & 18142.86 & 4.474849 & 0.0004 \\
\hline \hline R-squared & 0.764281 & Mean dependent var & 559.8364 \\
Adjusted R-squared & 0.690618 & S.D. dependent var & 48823.46 \\
S.E. of regression & 27156.62 & Akaike info criterion & 23.48363 \\
Sum squared resid & $1.18 E+10$ & Schwarz criterion & 23.78119 \\
Log likelihood & -252.3199 & Hannan-Quinn criter. & 23.55373 \\
F-statistic & 10.37547 & Durbin-Watson stat & 2.253247 \\
Prob(F-statistic) & 0.000142 & & \\
\hline \hline
\end{tabular}

Null Hypothesis: D(IMGER) has a unit root

Exogenous: Constant

Lag Length: 4 (Automatic - based on SIC, maxlag=6) 


\begin{tabular}{lccc} 
& \multicolumn{1}{c}{ t-Statistic } & Prob. $^{*}$ \\
\hline \hline \multicolumn{2}{l}{ Augmented Dickey-Fuller test statistic } & -3.853344 & 0.0083 \\
\hline Test critical values: & 1\% level & -3.769597 & \\
& $5 \%$ level & -3.004861 & \\
$10 \%$ level & -2.642242 & \\
\hline \hline
\end{tabular}

*MacKinnon (1996) one-sided p-values.

Augmented Dickey-Fuller Test Equation

Dependent Variable: D(IMGER,2)

Method: Least Squares

Date: 11/13/19 Time: 08:10

Sample (adjusted): 19972018

Included observations: 22 after adjustments

\begin{tabular}{lrlrl}
\hline \hline \multicolumn{1}{c}{ Variable } & Coefficient & Std. Error & t-Statistic & Prob. \\
\hline \hline D(IMGER(-1)) & -3.410837 & 0.885163 & -3.853344 & 0.0014 \\
D(IMGER(-1),2) & 1.949332 & 0.741834 & 2.627718 & 0.0183 \\
D(IMGER(-2),2) & 1.264317 & 0.573007 & 2.206459 & 0.0423 \\
D(IMGER(-3),2) & 0.666255 & 0.388578 & 1.714597 & 0.1057 \\
D(IMGER(-4),2) & 0.268745 & 0.233350 & 1.151682 & 0.2664 \\
\multicolumn{1}{c}{ C } & 132628.4 & 34685.99 & 3.823689 & 0.0015 \\
\hline \hline R-squared & 0.718954 & Mean dependent var & 2873.123 \\
Adjusted R-squared & 0.631127 & S.D. dependent var & 90178.81 \\
S.E. of regression & 54769.99 & Akaike info criterion & 24.88667 \\
Sum squared resid & $4.80 E+10$ & Schwarz criterion & 25.18423 \\
Log likelihood & -267.7534 & Hannan-Quinn criter. & 24.95677 \\
F-statistic & 8.186046 & Durbin-Watson stat & 2.125125 \\
Prob(F-statistic) & 0.000535 & & \\
\hline \hline
\end{tabular}

\section{Least squares method (regression analysis)}

Dependent Variable: D(GDPFRAN)

Method: Least Squares

Date: 11/12/19 Time: 21:39

Sample (adjusted): 228

Included observations: 27 after adjustments

\begin{tabular}{lrlrr}
\hline \hline \multicolumn{1}{c}{ Variable } & Coefficient & \multicolumn{1}{c}{ Std. Error } & t-Statistic & Prob. \\
\hline \multicolumn{1}{c}{ C } & 28053.88 & 6662.330 & 4.210821 & 0.0003 \\
\multicolumn{1}{c}{ D(GDPGER) } & 0.310432 & 0.077130 & 4.024776 & 0.0005 \\
\hline \hline R-squared & 0.393187 & Mean dependent var & 49117.03 \\
Adjusted R-squared & 0.368914 & S.D. dependent var & 26967.58 \\
S.E. of regression & 21423.30 & Akaike info criterion & 22.85353 \\
Sum squared resid & $1.15 E+10$ & Schwarz criterion & 22.94952 \\
Log likelihood & -306.5227 & Hannan-Quinn criter. & 22.88207 \\
F-statistic & 16.19882 & Durbin-Watson stat & 0.990237 \\
Prob(F-statistic) & 0.000465 & & \\
\hline
\end{tabular}


Dependent Variable: D(GDPGER)

Method: Least Squares

Date: 11/12/19 Time: 21:41

Sample (adjusted): 228

Included observations: 27 after adjustments

\begin{tabular}{lrlll}
\hline \hline \multicolumn{1}{c}{ Variable } & Coefficient & \multicolumn{1}{c}{ Std. Error } & t-Statistic & Prob. \\
\hline \multicolumn{1}{c}{ C } & 5640.529 & 17557.61 & 0.321258 & 0.7507 \\
\multicolumn{1}{c}{ D(GDPFRAN) } & 1.266577 & 0.314695 & 4.024776 & 0.0005 \\
\hline \hline R-squared & 0.393187 & Mean dependent var & 67851.04 \\
Adjusted R-squared & 0.368914 & S.D. dependent var & 54472.13 \\
S.E. of regression & 43273.17 & Akaike info criterion & 24.25964 \\
Sum squared resid & $4.68 E+10$ & Schwarz criterion & 24.35563 \\
Log likelihood & -325.5051 & Hannan-Quinn criter. & 24.28818 \\
F-statistic & 16.19882 & Durbin-Watson stat & 0.704164 \\
Prob(F-statistic) & 0.000465 & & \\
\hline
\end{tabular}

Dependent Variable: D(IMFRAN)

Method: Least Squares

Date: 11/12/19 Time: 22:35

Sample (adjusted): 19922018

Included observations: 27 after adjustments

\begin{tabular}{lrlrr}
\hline \hline \multicolumn{1}{c}{ Variable } & Coefficient & \multicolumn{1}{c}{ Std. Error } & t-Statistic & Prob. \\
\hline \hline \multicolumn{1}{c}{ C } & -1103.524 & 2530.976 & -0.436007 & 0.6666 \\
\multicolumn{1}{c}{ D(EXGER) } & 0.458583 & 0.033658 & 13.62484 & 0.0000 \\
\hline \hline R-squared & 0.881312 & Mean dependent var & 19751.19 \\
Adjusted R-squared & 0.876565 & S.D. dependent var & 29811.55 \\
S.E. of regression & 10473.81 & Akaike info criterion & 21.42233 \\
Sum squared resid & $2.74 \mathrm{E}+09$ & Schwarz criterion & 21.51832 \\
Log likelihood & -287.2014 & Hannan-Quinn criter. & 21.45087 \\
F-statistic & 185.6364 & Durbin-Watson stat & 2.106407 \\
Prob(F-statistic) & 0.000000 & & \\
\hline \hline
\end{tabular}

Dependent Variable: D(EXGER)

Method: Least Squares

Date: 11/12/19 Time: 22:38

Sample (adjusted): 19922018

Included observations: 27 after adjustments

\begin{tabular}{ccccc}
\hline \hline Variable & Coefficient & Std. Error & t-Statistic & Prob. \\
\hline \hline C & 7518.277 & 4978.814 & 1.510054 & 0.1436 \\
D(IMFRAN) & 1.921817 & 0.141052 & 13.62484 & 0.0000
\end{tabular}




\begin{tabular}{lrlr}
\hline \hline R-squared & 0.881312 & Mean dependent var & 45476.44 \\
Adjusted R-squared & 0.876565 & S.D. dependent var & 61028.36 \\
S.E. of regression & 21441.33 & Akaike info criterion & 22.85522 \\
Sum squared resid & $1.15 \mathrm{E}+10$ & Schwarz criterion & 22.95120 \\
Log likelihood & -306.5454 & Hannan-Quinn criter. & 22.88376 \\
F-statistic & 185.6364 & Durbin-Watson stat & 2.080387 \\
Prob(F-statistic) & 0.000000 & & \\
\hline \hline
\end{tabular}

Dependent Variable: D(IMGER)

Method: Least Squares

Date: 11/12/19 Time: 22:47

Sample (adjusted): 19922018

Included observations: 27 after adjustments

\begin{tabular}{lrlrr}
\hline \hline \multicolumn{1}{c}{ Variable } & Coefficient & \multicolumn{1}{c}{ Std. Error } & t-Statistic & Prob. \\
\hline \multicolumn{1}{c}{ C } & -1754.536 & 5419.414 & -0.323750 & 0.7488 \\
\multicolumn{1}{c}{ D(EXFRAN) } & 2.048609 & 0.172788 & 11.85619 & 0.0000 \\
\hline \hline R-squared & 0.849006 & Mean dependent var & 37571.51 \\
Adjusted R-squared & 0.842966 & S.D. dependent var & 56197.48 \\
S.E. of regression & 22269.67 & Akaike info criterion & 22.93103 \\
Sum squared resid & $1.24 \mathrm{E}+10$ & Schwarz criterion & 23.02701 \\
Log likelihood & -307.5689 & Hannan-Quinn criter. & 22.95957 \\
F-statistic & 140.5692 & Durbin-Watson stat & 1.505689 \\
Prob(F-statistic) & 0.000000 & & \\
\hline \hline
\end{tabular}

Dependent Variable: D(EXFRAN)

Method: Least Squares

Date: 11/12/19 Time: 22:48

Sample (adjusted): 19922018

Included observations: 27 after adjustments

\begin{tabular}{lrllr}
\hline \hline \multicolumn{1}{c}{ Variable } & Coefficient & \multicolumn{1}{c}{ Std. Error } & t-Statistic & Prob. \\
\hline \multicolumn{1}{c}{ D } & 3625.690 & 2332.510 & 1.554416 & 0.1327 \\
\multicolumn{1}{c}{ D(IMGER) } & 0.414430 & 0.034955 & 11.85619 & 0.0000 \\
\hline \hline R-squared & 0.849006 & Mean dependent var & 19196.47 \\
Adjusted R-squared & 0.842966 & S.D. dependent var & 25276.28 \\
S.E. of regression & 10016.36 & Akaike info criterion & 21.33301 \\
Sum squared resid & $2.51 E+09$ & Schwarz criterion & 21.42900 \\
Log likelihood & -285.9957 & Hannan-Quinn criter. & 21.36156 \\
F-statistic & 140.5692 & Durbin-Watson stat & 1.633813 \\
Prob(F-statistic) & 0.000000 & & \\
\hline \hline
\end{tabular}

